\title{
Effect of inter- and intra-row spacing on yield and yield components of mung bean (Vigna radiata L.) under rain-fed condition at Metema District, northwestern Ethiopia
}

\author{
Asaye Birhanu', ${ }^{1}$ Tilahun Tadesse ${ }^{2}$ and Daniel Tadesse ${ }^{3^{*}}$ (1)
}

\begin{abstract} (N-26). bean production in Metema District and similar agroecologies.

\section{Background}

Mung bean (Vigna radiata L.) is one of the most important pulse crops, grown from tropical to subtropical areas around the world [1]. It is an important wide-spreading, herbaceous and annual legume pulse crop cultivated mostly by traditional farmers [2]. At present, mung bean cultivation spreads widely in Africa, South America, Australia and in many Asian countries [3]. The world annual production area of mung bean is about 5.5 million hectare with a increase in rate of $2.5 \%$ per annum [4]. Its requirement in growing in areas where the rainy season is short, and its wide adaptability together with
\end{abstract}

Background: The study was conducted in 2017 main cropping season at two locations in North Gondar Zone, Ethiopia, to determine the optimum inter- and intra-row spacing of mung bean for maximum yield and yield components. The experiment was laid in a randomized complete block design with three replications in a factorial arrangement of four inter-row $(20,30,40$ and $50 \mathrm{~cm})$ and three intra-row $(5,10$ and $15 \mathrm{~cm})$ spacing using mung bean variety Rasa

Results: Significant interaction effect of inter- and intra-row spacing was observed for days to maturity, number of branches per plant, number of pods per plant, grain yield, harvest index, days to flowering, plant height and aboveground dry biomass yield. The highest grain yield $\left(1882.67 \mathrm{~kg} \mathrm{ha}^{-1}\right)$ was obtained at interaction of $40 \times 10 \mathrm{~cm} \mathrm{spac-}$ ing, while the lowest $\left(1367.8 \mathrm{~kg} \mathrm{ha}^{-1}\right.$ ) was obtained from $20 \times 5 \mathrm{~cm}$ spacing. However, the result of economic analysis showed that the maximum net benefit was obtained at spacing of $40 \times 15 \mathrm{~cm}$.

Conclusions: Based on agronomic performance and economic analysis, use of $40 \times 15 \mathrm{~cm}$ is promising for mung

Keywords: Economic analysis, Intra-row spacing, Plant spacing, Mung bean, Row spacing

\footnotetext{
*Correspondence: kaleabfather@gmail.com

${ }^{3}$ Department of Plant Sciences, University of Gondar, P.O. Box 196,

Gondar, Ethiopia

Full list of author information is available at the end of the article
}

its digestibility makes mung bean cultivated all over the world [3]. Mung bean is utilized in several ways; seeds, sprouts and young pods are all consumed and provide a rich source of amino acids, vitamins and minerals [5]. The grain contains $24.2 \%$ protein, $1.3 \%$ fat and $60.4 \%$ carbohydrate [6]. It has low calories and is rich in fiber and easily digestible crop without causing flatulence as happens with many other legumes [7]. The crop is characterized by fast growth under warm conditions, low water requirement and excellent soil fertility enhancement via nitrogen fixation [8]. Currently, mung bean is produced in different parts of Ethiopia. It is mainly cultivated in North Shewa, Harerge, Illubabor, Gamo Gofa, Tigray and Gondar. Farmers in some moisture stress areas of Ethiopia effectively use and produce it to supplement their protein needs [9]. Ethiopia's green mung bean export has grown slightly from 822 tons in (2001) to 26,743 tons in 
2014 to fulfill the demand of India, Indonesia, Belgium and the $\operatorname{UAE}[10,11]$. In Ethiopia, mung bean covers about 27,086 ha of land and produces 241,589.90 tons in main cropping season per annum with average productivity of 0.9 ton ha $^{-1}$ [12].

Even though there are high potential uses and export demand, the productivity of mung bean is low in Ethiopia ( 0.9 ton $\left.\mathrm{ha}^{-1}\right)$ as compared to the world average productivity of 1.2 ton ha ${ }^{-1}$, which is due to abiotic and biotic factors such as lack of improved variety, disease, insect and agronomic practices like in optimum row spacing and plant population per unit area. Proper method of sowing is among the important biotic factors that determine the proper plant population, which improves the performance and productivity of plants in the field. Plant population plays an important role as it is one of the most important yield contributing characters [13]. Combinations of researches on inter- and intra-row spacing is lacking in boosting productivity of mung bean in northwestern Ethiopia. Therefore, the present study was conducted to investigate the optimum inter- and intrarow spacing of mung bean for maximum yield and yield components and to evaluate the economic feasibility of different inter- and intra-row spacing of mung bean.

\section{Materials and methods}

The field experiment was conducted at Kumer and Kokit areas of Metema District from July to September 2017 in the main cropping season. Metema District is located in North Gondar Zone of Amhara Regional State, Ethiopia. Metema has latitude, longitude and elevation of $12^{\circ} 47^{\prime \prime} 38^{\prime} \mathrm{N}, 36^{\circ} 23^{\prime \prime} 41^{\prime} \mathrm{E}$ and $760 \mathrm{~m}$ above sea level, respectively. It has average annual rainfall of $1030 \mathrm{~mm}$. It has maximum and minimum temperatures of 40.0 and $15.0^{\circ} \mathrm{C}$, respectively [14]. The soil type is sandy loam and reddish brown color. The mung bean variety Rasa $(\mathrm{N}-26)$ was used for the experiment.
Factorial combinations of four inter-rows (20, 30, 40 and $50 \mathrm{~cm})$ and three intra-rows $(5,10$ and $15 \mathrm{~cm})$ spacing were laid out in a randomized complete block design with three replications. Each experimental plot had 2.5 and $4 \mathrm{~m}$ length and width, respectively. Spacing between plots and replications were 1 and $1.5 \mathrm{~m}$, respectively. Planting was done when there was adequate soil moisture in the field. DAP fertilizer was applied at a rate of $100 \mathrm{~kg} \mathrm{ha}^{-1}$, and all other management practices were performed as per the general recommendations for green bean [15].

Data were collected on major agronomic and phenological characters. Analysis of variance (ANOVA) was done using SAS software [16]. Homogeneity of variances was tested using $F$ test as described by Gomez and Gomez [17]. According to the homogeneity test, all parameters were homogenous except the number of branches per plant and number of pods per plant. As a result of it, the two parameters were analyzed in separate locations. Least significant differences (LSD) test at 5\% level of probability was used. The partial budget analysis as described by CIMMYT [18] was done to determine the economic feasibility. The net benefit was calculated as the difference between the gross field benefit (Ethiopian Birr ha ${ }^{-1}$ ) and the total costs (Ethiopian Birr ha ${ }^{-1}$ ) that varied.

\section{Results and discussion \\ Days to flowering}

The combined main effect of inter- and intra-row spacing was highly significant $(P<0.01)$, while their interaction had no significant effect on days to $50 \%$ flowering (Table 1). The longest days to $50 \%$ flowering $(40.83 \mathrm{~cm})$ were recorded at inter-row spacing of $50 \mathrm{~cm}$, while the shortest days to $50 \%$ flowering (36.05) were recorded at $20 \mathrm{~cm}$ inter-row spacing (Table 2). The longest days to $50 \%$ flowering $(39.86)$ were recorded at wider $(15 \mathrm{~cm})$

Table 1 The combined mean square values of ANOVA for phenology, growth and yield components of mung bean interand intra-rows spacing at Metema, 2017

\begin{tabular}{|c|c|c|c|c|c|c|c|c|c|c|}
\hline SOV & DoF & DF & DM & $\mathrm{PH}$ & $\mathrm{PL}$ & SPP & DBY $\left(\mathrm{kg} \mathrm{ha}^{-1}\right)$ & AGY $\left(\mathrm{kg} \mathrm{ha}^{-1}\right)$ & TSW & $\mathrm{HI}$ \\
\hline REP & 2 & $9.39 *$ & $0.79^{\text {ns }}$ & $219.50^{* *}$ & $0.28^{\mathrm{ns}}$ & $0.41^{\mathrm{ns}}$ & $108,938.01^{\mathrm{ns}}$ & $20,723.51^{*}$ & $0.18^{\mathrm{ns}}$ & $0.01^{\mathrm{ns}}$ \\
\hline PS & 2 & $27.18^{* *}$ & $10.13^{* *}$ & $337.89^{* *}$ & $0.074^{\mathrm{ns}}$ & $0.32^{\text {ns }}$ & $3,140,693.43^{* *}$ & $158,340.93^{* *}$ & $7.15^{\mathrm{ns}}$ & $0.10^{* *}$ \\
\hline RS & 3 & $91.13^{* *}$ & $40.53^{* *}$ & $191.65^{* *}$ & $0.40^{\text {ns }}$ & $0.36^{\text {ns }}$ & $11,827,511.24^{* *}$ & $175,899.87^{* *}$ & $29.47^{\mathrm{ns}}$ & $0.22^{* *}$ \\
\hline Site & 1 & $66.13^{* *}$ & $21.13^{* *}$ & $302.99 * *$ & $0.25^{\mathrm{ns}}$ & $0.002^{\text {ns }}$ & $375,700.01 *$ & $747.56^{\mathrm{ns}}$ & $1.75^{* *}$ & $0.01^{*}$ \\
\hline$R S^{*} P S$ & 6 & $0.79^{\mathrm{ns}}$ & $4.31^{* *}$ & $44.82^{n s}$ & $0.36^{\mathrm{ns}}$ & $0.27^{\mathrm{ns}}$ & $20,817.43^{\text {ns }}$ & $62,836.63^{* *}$ & $1.58^{\mathrm{ns}}$ & $0.01^{*}$ \\
\hline Error & 52 & 2.14 & 1.08 & 23.52 & 0.52 & 0.38 & $59,438.14$ & 5636.839 & 3.71 & 0.002 \\
\hline
\end{tabular}

NS nonsignificant, SOV source of variation, CV coefficient of variation, Rep replication, $P S$ plant spacing, $R S$ row spacing, $D F$ days to flowering, $D M$ days to maturity, $P H$ plant height, $P L$ pod length, SPP seed per pod, $D B Y$ dry biomass yield, $A G Y$ adjusted grain yield, $T S W$ thousand seed pod, $H I$ harvest index, $L S D$ least significant difference at $5 \%$

*Significant difference at $P<0.05 ;{ }^{* *}$ highly significant differences at $P<0.01$ 
Table 2 The combined main effects of inter- and intrarow spacing on days to $\mathbf{5 0 \%}$ flowering and plant height, and aboveground dry biomass yield mung bean at Metema, 2017

\begin{tabular}{lccc}
\hline & Days to flowering & Plant height & $\begin{array}{c}\text { Dry biomass } \\
\text { yield }\left(\mathbf{k g ~ h a} \mathbf{~}^{\mathbf{1}} \text { ) }\right.\end{array}$ \\
\hline \multicolumn{2}{l}{ Intra-rows (PS) } & & \\
5 & $37.75 \mathrm{c}$ & $80.43 \mathrm{a}$ & $4009.92 \mathrm{a}$ \\
10 & $38.92 \mathrm{~b}$ & $76.63 \mathrm{~b}$ & $3548.21 \mathrm{~b}$ \\
15 & $39.86 \mathrm{a}$ & $72.92 \mathrm{c}$ & $3296.67 \mathrm{c}$ \\
LSD (5\%) & 0.85 & 2.81 & 141.23 \\
Inter-rows (RS) & & \\
20 & $36.05 \mathrm{c}$ & $79.83 \mathrm{a}$ & $4503.11 \mathrm{a}$ \\
30 & $38 \mathrm{~b}$ & $77.16 \mathrm{a}$ & $3962.39 \mathrm{~b}$ \\
40 & $40.5 \mathrm{a}$ & $77.5 \mathrm{a}$ & $3400.44 \mathrm{c}$ \\
50 & $40.83 \mathrm{a}$ & $72.09 \mathrm{~b}$ & $2607.11 \mathrm{~d}$ \\
LSD (5\%) & 0.98 & 3.25 & 163.07 \\
CV (\%) & 3.76 & 6.33 & 6.74 \\
\hline
\end{tabular}

Means in the same column and the same letters are not significantly different at $5 \%$ level of probability

NS nonsignificant, $L S D$ least significant difference at $5 \%$ level of significant, $C V$ coefficient of variation in percent

intra-row spacing, while the shortest (37.75) were recorded at narrow $(5 \mathrm{~cm})$ intra-row spacing (Table 2). The longest days to flowering with a wider inter- and intra-row spacing might be due to the fact that more nutritional area available in the wider row spacing might have caused the crop to flower later than the narrower spacing. Furthermore, this result might be because wider spacing had a better light interception as compared to the narrow row spacing, resulting in more number of days to flowering of mung bean. This result is in line with Samih [19] who reported that when beans are planted at the lower planting densities, the plants required more number of days for flowering.

\section{Days to $90 \%$ maturity}

The combined main effect of inter- and intra-row spacing and their interaction was highly significant $(P<0.01)$ on days to $90 \%$ maturity (Table 1 ). The longest days to $90 \%$ maturity (65.17) were recorded at interaction of $50 \mathrm{~cm}$ inter- and $15 \mathrm{~cm}$ intra-row spacing, while the shortest days to $90 \%$ maturity $(60.5 \mathrm{~cm})$ was recorded at $20 \mathrm{~cm}$ inter- and $5 \mathrm{~cm}$ intra-row spacing (Table 3). The prolonged days to $90 \%$ maturity with the lowest population density or wider inter-row and intra-row spacing might be due to less competition of light interception, high availability of growth resources that promote luxurious growth enhanced the lateral growth and prolonged maturity. This result was not in line with that of Oad et al. [20]
Table 3 The combined interaction effect of interand inter-row spacing on days to $\mathbf{9 0 \%}$ maturity of mung bean at Metema, 2017

\begin{tabular}{llll}
\hline Inter-rows (RS) & \multicolumn{3}{l}{ Intra-rows (PS) } \\
\cline { 2 - 4 } & $\mathbf{5}$ & $\mathbf{1 0}$ & $\mathbf{1 5}$ \\
\hline 20 & $61.17 \mathrm{e}$ & $61.17 \mathrm{e}$ & $60.6 \mathrm{e}$ \\
30 & $60.5 \mathrm{e}$ & $62.5 \mathrm{dc}$ & $61.17 \mathrm{e}$ \\
40 & $61.5 \mathrm{de}$ & $63.17 \mathrm{bc}$ & $64.17 \mathrm{ba}$ \\
50 & $63.33 \mathrm{bc}$ & $64.17 \mathrm{ba}$ & $65.17 \mathrm{a}$ \\
LSD (5\%) & 1.28 & CV (\%) & 1.8
\end{tabular}

Means in the same column and the same letters are not significantly different at $5 \%$ level of probability

NS nonsignificant, LSD least significant difference at $5 \%$ level of significant, $C V$ coefficient of variation in percent

who stated that the interaction of wider inter- and intrarow spacing hastened maturity of safflower.

\section{Plant height $(\mathrm{cm})$}

The combined main effect of inter- and intra-row spacing was highly significant $(P<0.01)$, while their interaction had no significant effect on plant height (Table 1 ). The maximum plant height $(79.83 \mathrm{~cm})$ was recorded at interrow spacing of 20,30 and $40 \mathrm{~cm}$ (Table 2).

With regard to the effects of intra-row spacing, the maximum plant height $(80.43 \mathrm{~cm})$ was recorded at narrow intra-row spacing of $5 \mathrm{~cm}$ (Table 2). The present result is in line with Shamsi and Kobraee [21] who found taller plants were recorded at narrow spacing, while the shortest plants at wider spacing on mung bean.

\section{Number of branches per plant}

Results from the analysis of variance showed that both the main effect and their interaction effect of inter- and intra-row spacing were highly significant $(P<0.01)$ on the number of branches per plant at Metema site two (Table 4), whereas, at site one, the main effect was significant $(P<0.01)$, while their interaction had no significant effect on the number of branches per plant (Table 4$)$. The highest number of branches per plant (10.4) was obtained from $50 \times 15 \mathrm{~cm}$ inter- and intra-row spacing followed by 9.67 at $40 \times 15 \mathrm{~cm}$ (Table 5 ), while the lowest number of branches per plant (3.13) was found at $20 \times 5 \mathrm{~cm}$ at Metema site two (Table 5). This result was in line with El Naim et al. [22] who reported that the number of branches per plant was reduced with the increase in plant density. Moreover, our finding is in line with Mehmet [23] who stated that as spacing gets wider, there will be more interception of sunlight for photosynthesis, which results in the production of more nutrients for partitioning toward the development of more branches. 
Table 4 Mean square values of ANOVA for the number of branches per plant and pods per plant of mung bean as affected by inter- and intra-row spacing at Metema, Locations one and two, 2017

\begin{tabular}{lcccccc}
\hline SOV & DF & \multicolumn{2}{l}{ Location one } & & \multicolumn{2}{l}{ Location two } \\
\cline { 7 - 7 } \cline { 7 - 7 } & & NBPP & NPPP & & NBPP & NPPP \\
\hline REP & 2 & $5.04^{*}$ & $22.58^{\text {ns }}$ & & $2.42^{*}$ & $4.12^{\text {ns }}$ \\
PS & 2 & $25.88^{* *}$ & $206.92^{* *}$ & & $53.83^{* *}$ & $332.01^{* *}$ \\
RS & 3 & $16.08^{* *}$ & $196.11^{* *}$ & & $19.76^{* *}$ & $131.13^{* *}$ \\
RS*PS & 6 & $0.63^{\text {ns }}$ & $5.50^{\text {ns }}$ & & $3.55^{* *}$ & $17.13^{* *}$ \\
Error & 22 & 1.18 & 11.57 & & 0.45 & 2.89 \\
\hline
\end{tabular}

NS nonsignificant at $P<0.05$, Rep replication, $P S$ plant spacing, $R S$ row spacing, SOV source of variation, DoF degree of freedom, NBPP number of branches per plant, NPPP number of pods per plant

*Significant at $P<0.05$; **highly significant differences at $P<0.01$

Table 5 Interaction effect of inter- and intra-row spacing on number of branches per plant of mung bean at Metema Location two, 2017

\begin{tabular}{lllcl}
\hline Inter-rows (RS) & \multicolumn{2}{l}{ Intra-rows (PS) } & Mean \\
\cline { 2 - 4 } & $\mathbf{5}$ & $\mathbf{1 0}$ & $\mathbf{1 5}$ & \\
\hline 20 & $3.13 \mathrm{e}$ & $4.33 \mathrm{dc}$ & $5.27 \mathrm{c}$ & 4.24 \\
30 & $3.87 \mathrm{dc}$ & $4.8 \mathrm{dc}$ & $6.6 \mathrm{~b}$ & 5.09 \\
40 & $3.87 \mathrm{de}$ & $7.53 \mathrm{~b}$ & $9.67 \mathrm{a}$ & 7.02 \\
50 & $4.13 \mathrm{de}$ & $7.33 \mathrm{~b}$ & $10.4 \mathrm{a}$ & 7.29 \\
Mean & 3.75 & 6 & 7.98 & \\
LSD (5\%) & 1.13 & CV (\%) & 11.29 & \\
\hline
\end{tabular}

Means in the same column and the same letters are not significantly different at $5 \%$ level of probability

NS nonsignificant, $L S D$ least significant difference at $5 \%$ level of significant, $C V$ coefficient of variation in percent, $P S$ plant spacing, $R S$ row spacing

\section{Number of pods per plant}

Results from the analysis of variance indicated that both the main effect and their interaction effect of inter- and intra- row spacing were highly significant $(P<0.01)$ on the number of pods per plant (Table 4) at Metema site two. Similarly, the main effect of inter- and intra-row spacing at site two was significant $(P<0.01)$, while their interaction had no significant effect on the number of pods per plant (Table 4 ). The highest number of pods per plant (26.73) was obtained from $50 \times 15 \mathrm{~cm}$ inter- and intra-row spacing, while the lowest number of pods per plant (7.53) was found at $20 \times 5 \mathrm{~cm}$ at Metema site two (Table 6). This result was in line with Malek et al. [24] who reported that the number of pods per plant of lentil was significantly influenced by plant density.
Pod length $(\mathrm{cm})$, number of seeds per pod and thousand seed weight (gm)

In the current study, the combined analysis showed that both main effect and their interactions effect of interand intra-row spacing were not significant $(P<0.05)$ on pod length, number of seeds per pod and thousand seed weight (Table 1). This result was in line with Ihsanullah et al. [25] who stated that no significant effect of different row spacing and plant densities on pod length of mung bean. This result was in line with the finding of Ihsanullah et al. [25] who reported no significant effect of row spacing on number of seeds per pod of mung bean. The present result was in line with Lemlem [26] who obtained no significant effect of plant density on hundred seeds weight of soya bean.

\section{Aboveground dry biomass yield $\left(\mathrm{kg} \mathrm{ha}^{-1}\right)$}

The combined main effect of inter- and intra-row spacing was highly significant $(P<0.01)$, while their interaction had no significant effect on aboveground dry biomass yield (Table 1). The highest aboveground dry biomass yield ( $4503.11 \mathrm{~kg} \mathrm{ha}^{-1}$ ) was recorded at $20 \mathrm{~cm}$ inter-row spacing which was significantly decreased by wider spacing of 30,40 , and $50 \mathrm{~cm}$ spacing, while the lowest value for dry biomass yield $\left(2607.11 \mathrm{~kg} \mathrm{ha}^{-1}\right)$ was obtained at $50 \mathrm{~cm}$ inter-row spacing (Table 2). Regarding the effect of intra-row spacing, the aboveground dry biomass increased with a decrease in intra-row spacing where the highest aboveground dry biomass yield $\left(4009.92 \mathrm{~kg} \mathrm{ha}^{-1}\right)$ was recorded at narrow intra-row spacing of $5 \mathrm{~cm}$, which had a significant difference with $10 \mathrm{~cm}$, while the lowest aboveground dry biomass yield (3296.67 $\mathrm{kg} \mathrm{ha}^{-1}$ ) was recorded at wider intra-row spacing of $15 \mathrm{~cm}$ (Table 8). This result was in agreement with Solomon [27] who reported that dry biomass per hectare was significantly increased with increased plant density on haricot bean.

\section{Adjusted grain yield $\left(\mathrm{kg} \mathrm{ha}^{-1}\right)$}

The combined analysis showed main effect and their interaction effect of inter- and intra-row spacing which were highly significantly $(P<0.01)$ affected on grain yield of mung bean (Table 1). The highest adjusted grain yield of $1882.67 \mathrm{~kg} \mathrm{ha}^{-1}$ was obtained at interaction of $40 \times 10 \mathrm{~cm}$, while the lowest adjusted grain yields of 1367.83 and $1401.5 \mathrm{~kg} \mathrm{ha}^{-1}$ were obtained at interaction of $20 \times 5 \mathrm{~cm}$ and $50 \times 15 \mathrm{~cm}$ inter- and intra-row spacing, respectively (Table 7).

At very higher population $(20 \times 5 \mathrm{~cm})$, the adverse effect on the yield was noticed which might be due to intense interplant competition and floral abortion. 
Table 6 Interaction effect of intra- and inter-row spacing on number of pods per plant of mung bean crop at Metema location two, 2017

\begin{tabular}{llll}
\hline Inter-rows & \multicolumn{3}{l}{ Intra-rows } \\
\cline { 2 - 4 } & $\mathbf{5}$ & $\mathbf{1 0}$ & $\mathbf{1 5}$ \\
\hline 20 & $7.53 \mathrm{e}$ & $11.33 \mathrm{dc}$ & $13 \mathrm{c}$ \\
30 & $9.53 \mathrm{de}$ & $13.13 \mathrm{c}$ & $19 \mathrm{~b}$ \\
40 & $9.73 \mathrm{de}$ & $19.87 \mathrm{~b}$ & $21.53 \mathrm{~b}$ \\
50 & $11.73 \mathrm{dc}$ & $19.73 \mathrm{~b}$ & $26.73 \mathrm{a}$ \\
LSD (5\%) & 2.88 & & \\
CV (\%) & 11.16 & & \\
\hline
\end{tabular}

Means in the same column and the same letters are not significantly different at $5 \%$ level of probability

NS nonsignificant, LSD least significant difference at $5 \%$ level of significant, CV coefficient of variation in percent, $P S$ plant spacing, $R S$ row spacing

Table 7 The combined interaction effect of intraand inter-row spacing on adjusted grain yield $\left(\mathrm{kg} \mathrm{ha}^{-1}\right)$ of mung bean at Metema, 2017

\begin{tabular}{llll}
\hline Inter-rows (RS) & \multicolumn{3}{l}{ Intra-rows (PS) } \\
\cline { 2 - 4 } & $\mathbf{5}$ & $\mathbf{1 0}$ & $\mathbf{1 5}$ \\
\hline 20 & $1367.83 \mathrm{f}$ & $1492.67 \mathrm{ed}$ & $1609.33 \mathrm{cb}$ \\
30 & $1429.17 \mathrm{ef}$ & $1551.33 \mathrm{~cd}$ & $1597.17 \mathrm{cb}$ \\
40 & $1536.17 \mathrm{~cd}$ & $1882.67 \mathrm{a}$ & $1652.17 \mathrm{~b}$ \\
50 & $1491.83 \mathrm{ed}$ & $1533.83 \mathrm{~cd}$ & $1401.5 \mathrm{f}$ \\
LSD (5\%) & 87.731 & & \\
CV (\%) & 4.88 & & \\
\hline
\end{tabular}

Means in the same column and the same letters are not significantly different at $5 \%$ level of probability

NS nonsignificant, LSD least significant difference at $5 \%$ level of significant, $C V$ coefficient of variation in percent, $P S$ plant spacing, $R S$ row spacing

Table 8 The combined interaction effect of intraand inter-row spacing on harvest index of mung bean at Metema, 2017

\begin{tabular}{llll}
\hline Inter-rows (RS) & \multicolumn{3}{l}{ Intra-rows (PS) } \\
\cline { 2 - 4 } & $\mathbf{5}$ & $\mathbf{1 0}$ & $\mathbf{1 5}$ \\
\hline 20 & $0.28 \mathrm{~g}$ & $0.38 \mathrm{fg}$ & $0.39 \mathrm{fe}$ \\
30 & $0.33 \mathrm{~g}$ & $0.40 \mathrm{e}$ & $0.44 \mathrm{de}$ \\
40 & $0.41 \mathrm{e}$ & $0.58 \mathrm{ab}$ & $0.54 \mathrm{bc}$ \\
50 & $0.49 \mathrm{~cd}$ & $0.62 \mathrm{a}$ & $0.62 \mathrm{a}$ \\
$\mathrm{LSD}(5 \%)$ & 0.06 & $\mathrm{CV}(\%)$ & 10.57 \\
\hline
\end{tabular}

Means in the same column and the same letters are not significantly different at $5 \%$ level of probability

NS nonsignificant, LSD least significant difference at $5 \%$ level of significant, $C V$ coefficient of variation in percent
Besides, at spacing of $20 \mathrm{~cm} \times 5 \mathrm{~cm}$, the grain yield ha ${ }^{-1}$ was significantly higher as compared to the interaction of wider inter- and intra-row spacing $(50 \times 15 \mathrm{~cm})$, which showed that the main determinant of yield was the plant population which along with other yield attributes contributed toward a significant increase in grain yield (Table 7). This result was in line with Abuzar et al. [28] who observed that the lowest grain yield was recorded at the highest population. In Bangladesh, as well as in other countries, various experiments with improper spacing reduced the yield of mung bean up to $20-40 \%$ [29].

\section{Harvest index}

The combined main effect of intra- and inter-row spacing had a significant $(P<0.01)$ effect on harvest index (Table 1). Moreover, the interaction effect of intra- and inter-row spacing effect on harvest index was significant $(P<0.05)$ (Table 1$)$. The highest harvest index $(62 \%)$ was obtained at interaction of $(50 \times 10) \mathrm{cm}$ followed by $(50 \times 15) \mathrm{cm}$ spacing, while the lowest $(28 \%$ and $33 \%)$ harvest index was obtained at interaction of $(20 \times 5)$ and $(30 \times 5) \mathrm{cm}$, respectively (Table 8$)$. Similar result was reported by Khan et al. [30] who recorded maximum harvest index $(41.66 \%)$ at the highest row spacing $(45 \mathrm{~cm})$ of chickpea than $15 \mathrm{~cm}$ row spacing (32.6\%).

\section{Economic analysis}

Results of the economic analysis of the present experiment showed that the maximum net benefit of Ethiopian birr (ETB) 22,185.7 $\mathrm{ha}^{-1}$ with an acceptable marginal rate of return (MRR) (>100\%) was obtained from planting of mung bean with $40 \times 15 \mathrm{~cm}$ spacing (Table 9). Farmers may have the opportunity to decrease seed and labor cost and to increase mung bean yield and ultimately improve their livelihoods through adopting the appropriate management practices. The present finding demonstrated that optimum economic plant densities of mung bean are often less than densities that result in maximum yield, because of higher labor and seed costs at higher densities. This result is in line with [31] who reported that changes in seeding rates contributed to significant yield changes but not to changes in profitability.

\section{Conclusions}

Generating reliable information on agronomic management practices such as appropriate row and plant spacing is quite important to come up with profitable and sustainable mung bean production and productivity. In view of this, an experiment was conducted to determine the effect of intra- and inter-row spacing on the yield and yield components of mung bean. 
Table 9 Economic analysis for inter- and intra-row spacing of mung bean at Metema, 2017

\begin{tabular}{|c|c|c|c|c|c|c|c|}
\hline & $\begin{array}{l}\text { Average yield } \\
\left(\mathrm{kg} \mathrm{ha}^{-1}\right)\end{array}$ & $\begin{array}{l}\text { Adjusted yield 10\% } \\
\left(\mathrm{kg} \mathrm{ha}^{-1}\right)\end{array}$ & GB (ETB/ha) & TVC (ETB/ha) & & DA & \\
\hline $50 \times 15$ & 1367.83 & 1231.05 & $22,158.85$ & 3599.305 & 19,105 & - & \\
\hline $40 \times 15$ & 1492.67 & 1343.40 & $24,181.25$ & 4579.456 & $22,185.7$ & - & 314.308 \\
\hline $50 \times 10$ & 1609.33 & 1448.40 & $26,071.15$ & 5621.72 & $19,226.33$ & D & \\
\hline $30 \times 15$ & 1429.17 & 1286.25 & $23,152.55$ & 5956.173 & $19,917.98$ & D & \\
\hline $40 \times 10$ & 1551.33 & 1396.20 & $25,131.55$ & 7144.15 & $23,355.1$ & - & 45.596 \\
\hline $20 \times 15$ & 1597.17 & 1437.45 & $25,874.15$ & 9155.312 & $16,915.83$ & D & \\
\hline $30 \times 10$ & 1536.17 & 1382.55 & $24,885.95$ & 9294.595 & $15,836.95$ & D & \\
\hline $50 \times 5$ & 1882.67 & 1694.40 & $30,499.25$ & $11,243.44$ & $12,924.21$ & $\mathrm{D}$ & \\
\hline $20 \times 10$ & 1652.17 & 1486.95 & $26,765.15$ & $14,288.3$ & 9892.954 & $\mathrm{D}$ & \\
\hline $40 \times 5$ & 1491.83 & 1342.65 & $24,167.65$ & $14,288.3$ & $10,597.65$ & D & \\
\hline $30 \times 5$ & 1533.83 & 1380.45 & $24,848.05$ & $18,587.39$ & 4565.164 & D & \\
\hline $20 \times 5$ & 1401.5 & 1261.35 & $22,704.30$ & $28,576.6$ & -6417.75 & D & \\
\hline
\end{tabular}

GB gross benefit, ETB Ethiopian birr, TVC total variable cost, NB net benefit, DA dominance analysis, MRR marginal rate of return

This study provides evidence that inter- and intra-row spacing has influence on the phenology, growth, yield and yield components of mung bean. However, for maximum net benefit, we recommend spacing of $40 \times 15 \mathrm{~cm}$ as the optimum spacing for the cultivation of mung bean variety Rasa (N-26) under the rain-fed in North Gondar Zone, Metema Districts, and similar agroecologies.

\section{Abbreviations}

ANOVA: analysis of variance; ETB: Ethiopian birr; MRR: marginal rate of return.

\section{Authors' contributions}

$A B$ initiated the research, wrote the research proposal, conducted the research, did data entry and analysis and wrote the manuscript. TT and DT were involved in analysis, methodology, writing, reviewing and editing of research proposal and manuscript. All authors read and approved the final manuscript.

\section{Author details}

${ }^{1}$ Gondar Agricultural Research Center, P.O. Box 1337, Gondar, Ethiopia. ${ }^{2}$ Fogera National Rice Agricultural Research Center, P.O. Box 1937, Woreta, Ethiopia. ${ }^{3}$ Department of Plant Sciences, University of Gondar, P.O. Box 196, Gondar, Ethiopia.

\section{Acknowledgements}

We would like to acknowledge Gondar Agricultural Research Center for providing seed and equipment for measuring various traits. University of Gondar is also acknowledged for accepting AB as a Master of Science student in Agronomy discipline.

\section{Competing interests}

The authors declare that they have no competing interests.

\section{Availability of data and materials}

The authors want to declare that they can submit the data at whatever time based on your request. The datasets used and/or analyzed during the current study will be available from the corresponding author on reasonable request.

\section{Consent for publication}

Not applicable.
Ethics approval and consent to participate

Not applicable since the study involved mung bean plants.

Funding

No funding was received toward this study.

\section{Publisher's Note}

Springer Nature remains neutral with regard to jurisdictional claims in published maps and institutional affiliations.

Received: 29 September 2018 Accepted: 3 November 2018

Published online: 20 November 2018

\section{References}

1. Kumar SG, Gomathinayajam P, Rathnaswmy R. Effect of row spacing on a dry matter accumulation of black gram. Madras Agric J. 1997;84(3):160-2.

2. Ali MZ, Khan MA, Rahaman AK, Ahmed M, Ahsan AF. Study on seed quality and performance of some mung bean varieties in Bangladesh. Int J Exp Agric. 2010;1(2):10-5.

3. Gebre Wedajo. Adaptation study of improved mung bean (Vigna radiata L) varieties at Alduba, south Omo Ethiopia. Res J Agric Environ Manag. 2015;4(8):339-42

4. Tomooka N, Vaughan DA, Kaga A. Mung bean (Vigna radiata L. Wilczek). In: Singh RJ, Jauhar PP, editors. Chromosome engineering and crop improvement: grain legumes genetic resources. Boca Raton: CRC Press; 2005.

5. Somta P, Srinives P. Genome research in mung bean (Vigna radiata L. Wilczek) and black gram (Vigna mungo L. Hepper). Sci Asia. 2007;33(1):69-74.

6. Hussain M, Mehmood Z, Khan MB, Farooq S, Lee DJ, Farooq M. Narrow row spacing ensures higher productivity of low tillering wheat cultivars. Int J Agric Biol. 2012;14:413-8.

7. Minh NP. Different factors affecting to mung bean (Phaseolus aureus) tofu production. Int J Multidiscip Res Dev. 2014;1(4):105-10.

8. Yagoob $\mathrm{H}$, Yagoob M. The effects of water deficit stress on protein yield of mung bean genotypes. Peak J Agric Sci. 2014;2(3):30-5.

9. Asfaw A, Fekadue Gurum F, Alemayehu S, Rezene Y. Analysis of multi-environment grain yield trials in mung bean (Vigna radiate L. Wilczek) based on GGE bi plot in Southern Ethiopia. J Agric Sci Technol. 2012;14:389-98.

10. MoARD (Ministry of Agriculture and Rural Development). Crop variety register. Animal and Plant Health Regulatory Directorate, Issue No. 12. Addis Ababa, Ethiopia; 2008. p. 96-103. 
11. MoARD (Ministry of Agriculture and Rural Development). Crop variety register. Animal and Plant Health Regulatory Directorate, Issue No. 12. Addis Ababa, Ethiopia; 2015. p. 96-103.

12. CSA (Central Statistical Authority). Agricultural sample survey 2008/2009: report on area and production of crops (private peasant holdings 'Meher' season). Addis Ababa Ethiopia, the FDRE statistical bulletin, Vol. IV; 2016.

13. Rafiei M. Influence of tillage and plant density on mung bean. Am Eur J Sustain Agric. 2009;3:877-80.

14. NMSA (National Metrological Services Agency) Bahir Dar Branch. 2017.

15. Dessalegn L. Snap bean production and research status (Phaseolus vulgaris L.) in Ethiopia. Nazret: Melkassa Agricultural Research Center; 2003.

16. SAS (Statistical Analysis System). SAS Version 9.1 @ 2001-2002. Cary, NC: SAS Institute, Inc.; 2002

17. Gomez KA, Gomez AA. Statistical procedures for agricultural research. 2nd ed. New York: Wiley; 1984

18. CIMMYT (International Maize and Wheat Improvement Center). From agronomic data to farmer recommendations: an economics training manual. Texcoco: CIMMYT (International Maize and Wheat Improvement Center); 1988 (completely revised edition).

19. Samih A. Effect of plant density on flowering date, yield and quality attribute of bush beans (Phaseolus Vulgaris L.) under center pivot irrigation system. Am J Agric Biol Sci. 2008;3(4):666-8.

20. Oad FC, Samo MA, Qayylan SM, Oad NL. Inter and intra row spacing effect on the growth, seed yield and oil continent of safflower. Asian Plant Sci J. 2002;1:18-9.

21. Shamsi K, Kobraee S. Effect of plant density on the growth, yield and yield components of three soybean varieties under climatic conditions of Kermanshah, Iran. Anim Plant Sci J. 2009;2(2):96-9.

22. El-Noemani AA, El-Zeiny HA, El-Gindy AM, Sahhar EA, El-Shawadfy MA Performance of some bean (Phaseolus Vulgaris L.) varieties under different irrigation systems and regimes. Aust J Basic Appl Sci. 2010;4:6185-96.
23. Mehmet OZ. Nitrogen rate and plant population effects on yield and yield components in soybean. Afr Biotechnol J. 2008;7(24):4464-70.

24. Malek MFN, Majnonhoseini N, Alizade H. A survey on the effects of weed control treatments and plant density on lentil growth and yield. Eur J Clin Pharmacol. 2013:6:135-48.

25. Ihsanullah F, Taj H, Akbar H, Basir A, Noor U. Effect of row spacing on the agronomic traits and yield of mung bean (Vigna radiata L. Wilczek). Asian J Plant Sci. 2002;1 (4):328-9.

26. Lemlem HG. Effect of $\mathrm{N}$ fertilizer and plant density on yield, seed quality, and oil content of soybean (Glycine max L. Merr) at Hawassa, southern Ethiopia. M.Sc. thesis presented to Haramaya University, Ethiopia; 2011.

27. Abate $\mathrm{S}$. Effects of irrigation frequency and plant population density on growth, yield components and yield of haricot bean (Phaseolus vulgaris L.) in Dire Dawa area. M.Sc. thesis presented to Haramaya University, Ethiopia; 2003.

28. Abuzar MR, Sadozai GU, Baloch MS, Baloch AA, Shah IH, Javaid T, Hussain N. Effect of plant population densities on yield of maize. J Anim Plant Sci. 2011;21(4):692-5.

29. Mondal MMA. A study of source-sink relation in mung bean. Ph.D. dissertation. Department of Crop Botany, Bangladesh Agriculture University, Mymensingh; 2007. p. 82-84.

30. Khan EA, Aslam M, Ahmad HK, Ayaz M, Hussain A. Effect of row spacing and seeding rates on growth yield and yield components of chickpea. Sarhad J Agric. 2010;26(2):201-11.

31. De Bruin JL, Pedersen P. Effect of row spacing and seeding rate on soybean yield in the Upper Midwest. Agron J. 2008;100:696-703.

32. Hashemijazi SM, Danesh A, Gani B. Effects of plant arrangement on yield and yield components of Soya bean. In: Proceedings of the 1st Iranian Pulse Symposium, November 20-21, 2005, IEEE Xplore; 2005. p. 208-209.
Ready to submit your research? Choose BMC and benefit from:

- fast, convenient online submission

- thorough peer review by experienced researchers in your field

- rapid publication on acceptance

- support for research data, including large and complex data types

- gold Open Access which fosters wider collaboration and increased citations

- maximum visibility for your research: over 100M website views per year

At BMC, research is always in progress.

Learn more biomedcentral.com/submissions 